\title{
The mating behavior of Leucothyreus marginaticollis Blanchard, 1843 (Coleoptera: Scarabaeidae: Rutelinae)
}

\author{
Kleyton Rezende Ferreira ${ }^{1}$ \& Sérgio Roberto Rodrigues ${ }^{* 2}$ \\ ${ }^{1}$ Instituto Técnico Federal de Mato Grosso, Juina, MT, Brazil \\ ${ }^{2}$ Universidade Estadual de Mato Grosso do Sul, Cassilândia, MS, Brazil \\ *Corresponding author: Sérgio Roberto Rodrigues, e-mail: sergio@uems.br
}

FERREIRA, K. R., RODRIGUES, R. The mating behavior of Leucothyreus marginaticollis Blanchard, 1843. Biota Neotropica. 17(4): e20170330. http://dx.doi.org/10.1590/1676-0611-BN-2017-0330

\begin{abstract}
In Brazil, there are several species of the genus Leucothyreus Macleay, 1819 occurring throughout the country; however, there are only a few studies describing their biological aspects, times of occurrence, associations of adults and juveniles with native or cropped plants, as well as their mating behavior. Thus, this study aimed to assess the mating behavior of Leucothyreus marginaticollis Blanchard, 1843. The study took place in an experimental area of the State University of Mato Grosso do Sul, in Aquidauana, MS, Brazil. Firstly, we sampled adult insects using light traps, from October to November 2013. Simultaneously, we registered the flight period in the field. Afterward, in the laboratory, males and females were separated and then combined into couples for observations of the mating steps. A large number of the adults mated, which lasted on average $22.71 \mathrm{~min}$ and occurred from 7 to $11 \mathrm{pm}$. After mating, part of the males released the females and the other part remained attached to them, which must have happened as an attempt to inhibit other males from mating with them. Moreover, a few females refused to mate with the established male, reinforcing the fact that the pairing of couples occurs after chemical identification among adults. In the field, the largest amount of adults was collected from 8 to $10 \mathrm{pm}$. Regarding eating habits, adults feed mostly on acerola leaves and flowers (Malpighia emarginata DC, Malpighiaceae), mastic gum leaves (Myracrodruon urundeuva Allemão, Anacardiaceae), grapes (Vitis vinifera L., Vitaceae), apples (Malus domestica Borkh., Rosaceae), and bananas (Musa sp. L., Musaceae). To the end of the experiment, we could clarify the mating steps of L. marginaticollis in order to assist in further extraction and identification of sexual pheromone.
\end{abstract}

Keywords: Chemical communication, eating habit, Geniatini, Scarabaeoidea, white grubs.

\section{Comportamento de cópula de Leucothyreus marginaticollis Blanchard, 1843 (Coleoptera: Scarabaeidae: Rutelinae)}

Resumo: No Brasil várias são as espécies de Leucothyreus Macleay, 1819 que ocorrem nas diferentes regiões, entretanto, poucos são os trabalhos que descrevem os aspectos biológicos, épocas de ocorrência, associação de adultos e imaturos com plantas nativas ou cultivadas, e comportamento de cópula. Assim o presente trabalho apresentou como objetivo estudar o comportamento de cópula de Leucothyreus marginaticollis Blanchard, 1843. Os estudos foram conduzidos na fazenda experimental da Universidade Estadual de Mato Grosso do Sul em Aquidauana, MS, sendo realizadas coletas de adultos com armadilha luminosa de outubro a novembro de 2013. Com as coletas foram analisados os horários de voo em campo, e em laboratório machos e fêmeas foram separados, posteriormente foram formados casais e as etapas que envolvem o comportamento de cópula, verificadas. Vários adultos realizaram cópula, a qual durou em média 22,71 minutos e ocorreram das 19 às 23 horas. Após a cópula o macho se soltava da fêmea ou permanecia sobre essa, provavelmente para impedir que outro macho realizasse a cópula. Algumas fêmeas não aceitaram os machos para cópula, indicando que a formação de casais ocorre após o reconhecimento químico entre os adultos. O horário de maior coleta dos adultos em campo foi das 20 às 22 horas. Adultos podem se nutrir de folhas e flores de acerola (Malpighia emarginata DC, Malpighiaceae), folhas de aroeira (Myracrodruon urundeuva Allemão, Anacardiacea), frutos de uva (Vitis vinifera L., Vitaceae), maçã (Malus domestica Borkh., Rosaceae) e banana (Musa sp. L., Musaceae), ampliando-se as informações sobre o hábito alimentar dos adultos. Foram elucidadas as etapas relacionadas ao comportamento de cópula de L. marginaticollis, a qual pode auxiliar nos processos de extração e identificação de feromônio sexual.

Palavras-chaves: Comunicação química, hábito alimentar, Geniatini, Scarabaeoidea, corós. 


\section{Introduction}

A total of 164 species has been identified in the genus Leucothyreus Macleay, 1819. These species can be found from the southern Mexico to Uruguay (Jameson \& Hawkins 2005). In Brazil, Morón (2004) reported 83 species of this genus in several regions. Adult dimensions range from 8.0 to $18.0 \mathrm{~mm}$, being in general of dark brown, brown, or black coloration (Jameson \& Hawkins 2005).

Just a few species stand out as crop pests, however causing significant losses. In Colombia, larvae of L. femoratus Burmeister, 1844 are listed as crop and pasture pests (Pardo-Locarno et al. 2003, 2005, 2006), as well as for African oil palm (Elaeis guineensis Jacquin, Arecaceae) (Martinez \& Plata-Rueda 2013, Martinez et al. 2013). In Mexico, Ramírez-Salinas \& Castro-Ramírez (2000) labeled Leucothyreus species as major pests for corn (Zea mays L., Poaceae).

In Brazil, only a few species are recorded as belonging to the genus Leucothyreus. One of these records was made by Puker et al. (2011), who reported L. albopilosus Ohaus, 1917 in lesions of Eucalyptus citriodora Hook (Myrtaceae). Pereira et al. (2013) sampled larvae of L. alvarengai Frey, 1976 and of $L$. aff. semipruinosus Ohaus, 1917 in crop succession systems of soybeans (Glycine $\max$ (L.) Merr., Fabaceae) and maize (Zea mays L., Poaceae). Yet Rodrigues \& Pereira (2014) observed larvae of Leucothyreus sp. and of $L$. aff. ambrosius Blanchard, 1850 in a succession system of soybeans and cotton (Gossypium hirsutum L., Malvaceae).

The biological aspects of certain species are already known. The lifecycle of L. femoratus is completed within 170.4 days (Martínez \& Plata-Rueda 2013), while those of L. alvarengai and of $L$. aff. semipruinosus are fulfilled in less than one year (Pereira et al. 2013). For L. ambrosius, the end of the lifecycle is reached within 173.3 days (Gomes et al. 2014); yet for L. albopilosus, it lasts 185.5 days (Ferreira et al. 2016).

When it comes to mating behavior, little information is known about this genus. As an example, we may cite the study by Ferreira et al. (2016) for L. albopilosus, which detailed the several steps involving this aspect, as well as the possible release of sexual pheromone by females.

In view of such scarcity of information on the genus Leucothyreus, we developed a study on the mating behavior of L. marginaticollis Blanchard, 1843. This species (cited as L. dorsalis) ends its lifecycle within 273.5 days (Rodrigues et al., 2010) and there are reports stating that juveniles feed on palm roots (Acrocomia aculeata (Jacq.) Lodd. ex Mart., Arecaceae) (Puker et al. 2009). In brief, the present study aimed to elucidate the mating behavior of $L$. marginaticollis for purposes of future extraction and isolation of its sex pheromone.

\section{Material and Methods}

The studies were carried out at the experimental farm of the State University of Mato Grosso do Sul (UEMS), in Aquidauana, MS, Brazil (lat. 20 $28^{\prime}$; long. $55^{\circ} 48^{\prime}$ ). The local climate is $A w$ subtype according to the Köppen (1948) classification. The rainy season goes from October to March, with an average temperature of $28^{\circ} \mathrm{C}$; and the dry one is from April to September, with an average temperature of $22^{\circ} \mathrm{C}$. The average annual rainfall is about $1,400 \mathrm{~mm}$.

At first, adults of L. marginaticollis were collected with the aid of a light trap, "Luiz de Queiroz" model, between October and November 2013. Adults were collected from 6 p.m. to 6 a.m. the next day. The adults were identified by comparing specimens deposited in the collection of the laboratory of entomology, UEMS Aquidauana, wich had been identified by Dr. Sérgio Ide (Instituto Biológico, São Paulo, SP, Brazil). The sampled insects were taken to the Laboratory of Entomology, State University of
Mato Grosso do Sul (UEMS). Five adult couples were deposited at the Museu de Zoologia da Universidade de São Paulo (USP). Then, males and females were separated, being placed individually in $50 \mathrm{~mL}$ plastic containers. Half of the volume of these containers was filled with soil, being closed with a voile-type fabric. Sex differentiation was performed visually through protarsomers, which are enlarged in males (Figure 1).

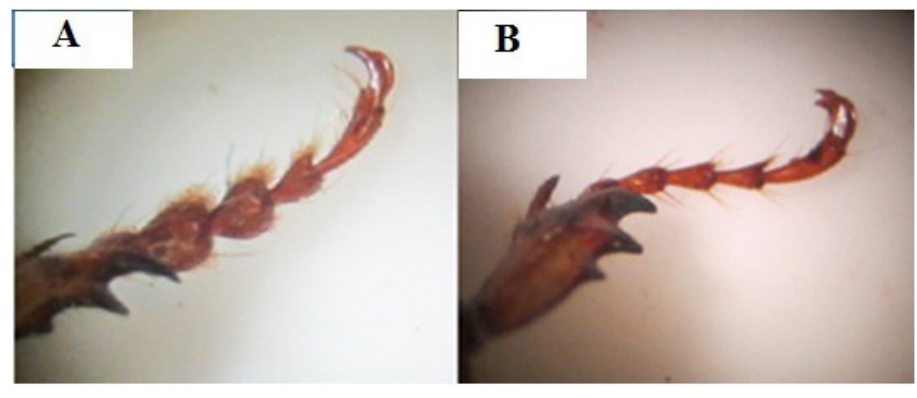

Figure 1. Protarsomers of Leucothyreus marginaticollis Blanchard (1843): A) Male; and B) Female.

In the laboratory the study of mating behavior was carried out from 05 to 28 October. At dusk, as soon as the adults emerged from the soil, observations began and, after that, couples (male and female) were paired and transferred to $1,000 \mathrm{~mL}$ plastic containers, as the method described by Rodrigues et al. (2014). Each container held two couples, which were used for the evaluation of mating outcome. The containers were filled with soil, for about one-third of its volume. Then, pieces of fruits, leaves, and flowers of different plant species were provided to the insects, so we could analyze their feeding habits. During the study period, 70 couples $(n=70)$ were paired; and 20 females $(n=20)$ were dissected to check for egg development.

The observation room was in the dark as stated by Facundo et al. (1999); and, in order to visualize and record the mating behavior of males and females, we used a camcorder (Canon SX160 IS).

From October 28 to November 4, 2013, adult flight time was monitored with the aid of a light trap, which was inspected at 60 minute intervals by counting the number of sampled insects. Flight time data were transformed into $\sqrt{x+1}$ and subjected to analysis of variance (ANOVA). The means compared by the Scott-Knott's test $(\mathrm{P}<0.01)$. For these statistics, we used ASSISTAT software package (Silva \& Azevedo 2002). Data of temperature $\left({ }^{\circ} \mathrm{C}\right)$, rainfall $(\mathrm{mm})$, and solar radiation $\left(\mathrm{kJ} / \mathrm{m}^{2}\right)$ for Aquidauana, MS were gathered from the Brazilian Institute of Meteorology (INMET).

\section{Results}

The adults kept in the observation containers remained during the daytime sheltered in the soil. At dusk, from 5:50 p.m. to 8:20 p.m., a small portion of the clypeus of insects was protruded from the soil surface, remaining at this position for on average $25.85 \pm 12.40$ (10-50) minutes. At that time, antennae remained raised with clubs open, probably in search for environmental chemical information. Next, adults left the soil for flying and walking inside containers for about $26.25 \pm 7.7$ (15-40) minutes. After this, the adults stood still and hence couples were paired. After being paired, several steps related to the mating behavior could be recorded and described (Figures 2 and 3a).

For most of the pairs, there were no approach responses for adults $(n=47)$, which remained either walking or feeding $(n=42)$, and some of them returned to the interior of the soil $(n=5)$. 
On the other hand, approach responses were observed for 23 pairs of adults. In these cases, males found females by touching them on the back $(n=17)$ or on the sides $(n=6)$ using antennas and protarsomers (Figures $3 \mathrm{~b}$ and $3 \mathrm{c}$ ). After meeting, males mounted on females, positioning themselves to start the mating process (Figure 3d). From that moment on, females showed two kinds of behavior: part of them walked and rolled on the ground moving their elytra to get rid of the males $(n=9)$ and refuse to mate, while the other part accepted the male $(n=14)$ and allowed copulation (Figure $3 e)$.
At the beginning of the mating, males bent their bodies until reaching female pygidium and then inserting their aedeagus. During this event, some females $(n=4)$ walked and others stood still $(n=10)$. The mating process lasted on average $22.71 \pm 4.71$ (15-31) minutes, occurring between 7 p.m. and 11 p.m., with twelve of them being recorded between 8 p.m. and 10 p.m. At the end of the mating, males retracted their aedeagus in $14.86 \pm 3.08(12-21)$ seconds.

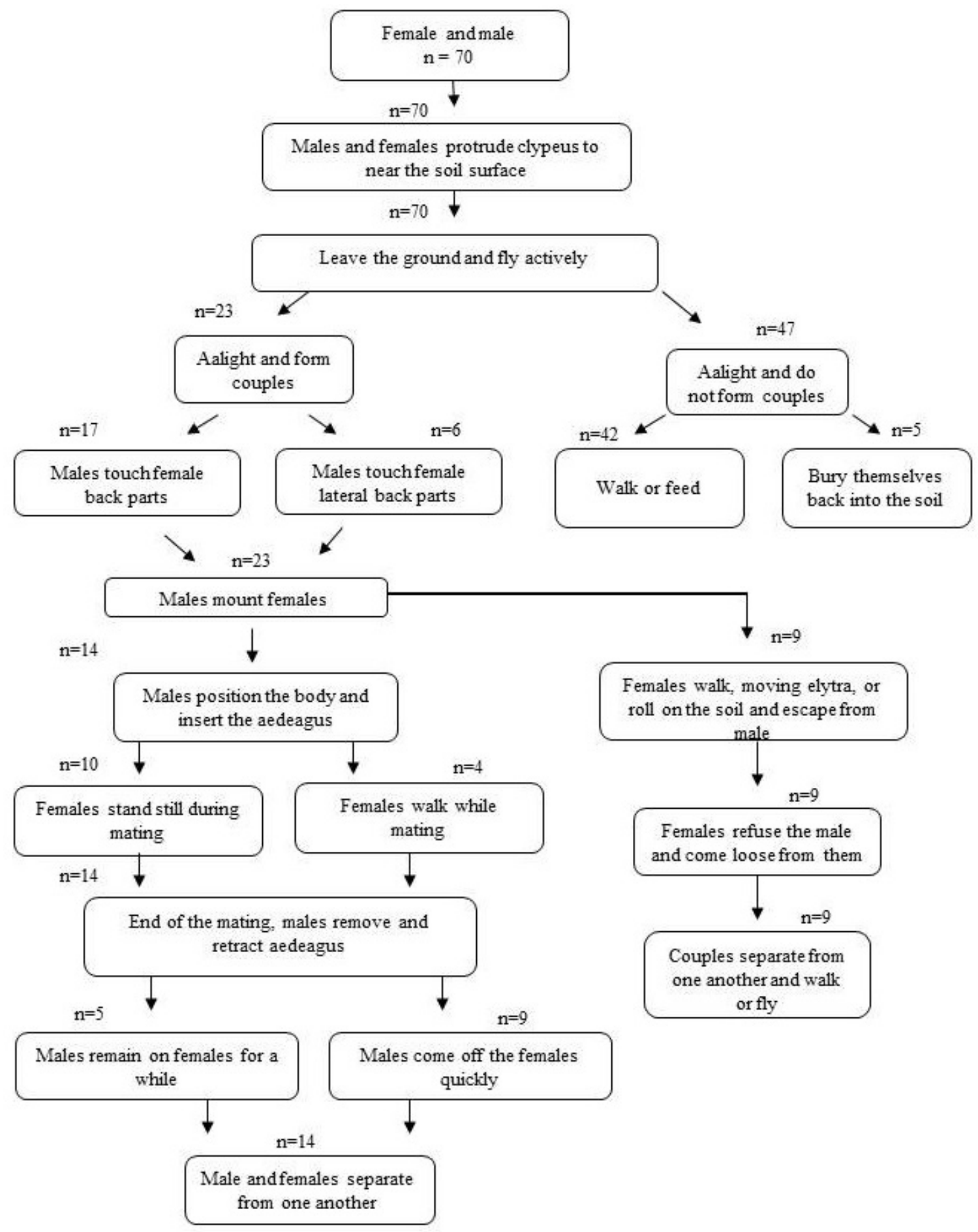

Figure 2. Ethogram of the mating behavior of Leucothyreus marginaticollis Blanchard (1843) ( $\mathrm{n}=70$ pairs), in the laboratory. 

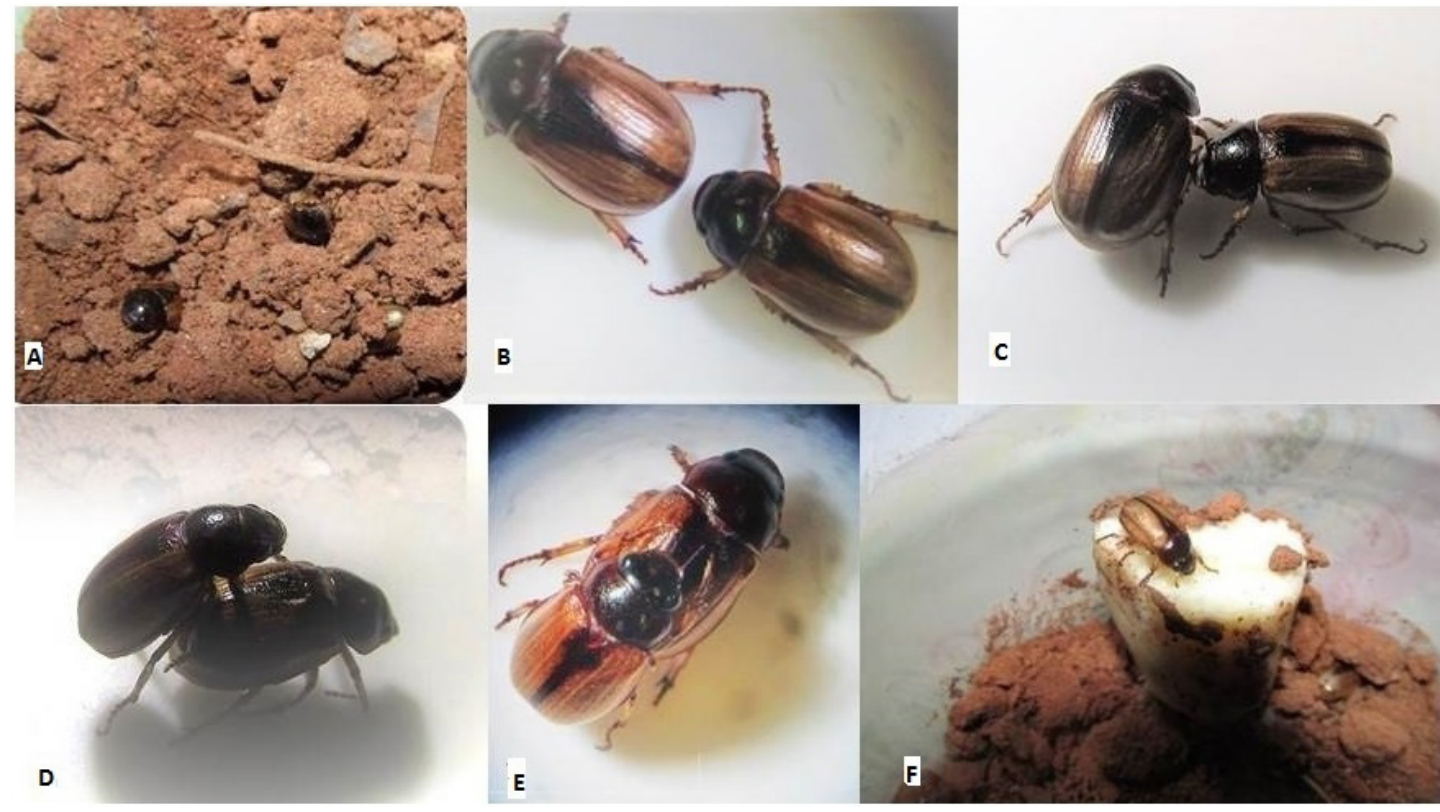

c

Figure 3. Leucothyreus marginaticollis Blanchard, 1843. A) Adults coming off the soil. B) Male meets female and touches the back body. C) Male meets the female and touches the side of her body. D) Male climbs on the female and stands for mating. E) Couple in mating. F) Adult feeding on piece of banana fruit.

A

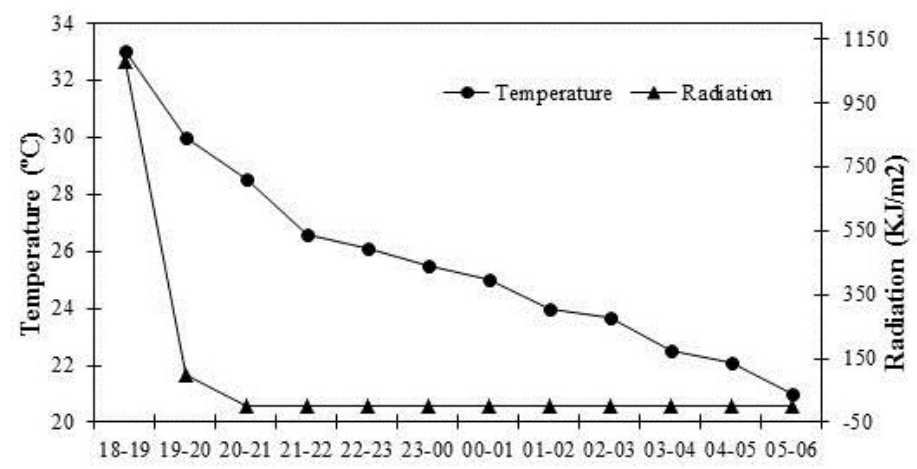

B

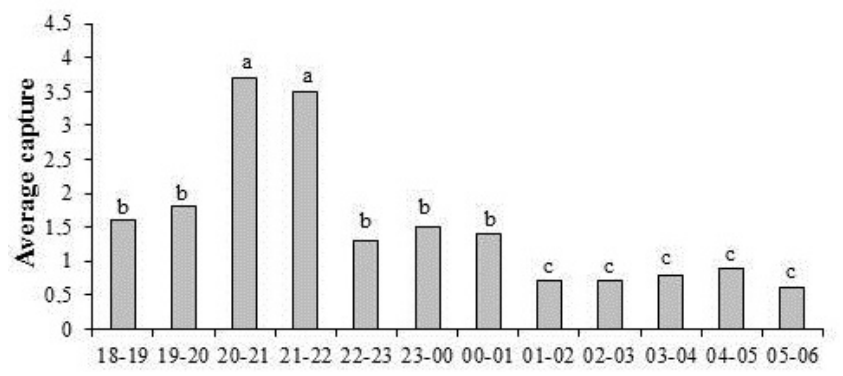

Times (Hours)

Figure 4. A) Averages of temperature $\left({ }^{\circ} \mathrm{C}\right)$ and radiation $\left(\mathrm{KJ} / \mathrm{m}^{2}\right)$ gathered a weather station (INMET). B) Mean number of adults of Leucothyreus marginaticollis Blanchard (1843) at different observation times. Means followed by the same letters do not differ from each other by the Scott-Knott's test ( $<<0.01$ ), data were converted into $\sqrt{x+1}$. Data collected from October 28 to November 4 of 2013 .
After retracting the aedeagus, some males immediately dismounted the females $(n=9)$ and others $(n=5)$ remained mounted for around $140.2 \pm 8.84$ (130-152) seconds. Afterward, they walked, flew, or fed and later returned to the interior of the ground.

Among the several types of leaves, flowers, and fruits provided for the feeding of adults, we noted a preference for flowers of acerola (Malpighia emarginata DC, Malpighiaceae), leaves of mastic gum (Myracrodruon urundeuva Allemão, Anacardiaceae), and fruits of grapevine (Vitis vinifera L., Vitaceae), apple (Malus domestica Borkh., Rosaceae), and banana (Musa sp. L., Musaceae) (Figure 3f).

Regarding the flight time, the first adults began to be sampled by the light trap from 6 p.m., which coincided with the beginning of the scotophase (dark period), from 6 p.m. to 7 p.m., when radiation decreased from 1,080 to $100 \mathrm{~kJ} / \mathrm{m}^{2}$ (Figure 4). Therefore, a reduction or absence of sunlight may stimulate adults to initiate flight activities. During flying hours, the mean temperature ranged from 33 to $21^{\circ} \mathrm{C}$ (Figure 4).

All dissected females had developing eggs. We found an average of $8.8 \pm 5.02(2-17)(n=20)$ developing eggs, proving that during the time of collection, females are within the reproductive period.

\section{Discussion}

The adults of L. marginaticollis in designing the clypeus near the surface of the ground, demonstrate the use of the visual stimuli, then with moving of antennae are detecting chemical information of the environment. For some species of Scarabaeidae, a number of antennal sensilla have been detected in the antennae, being more numerous in males, such as for the species Phyllophaga obsoleta (Blanchard, 1851) (Romero-Lópes et al. 2004) and $P$. anxia (LeConte, 1850) (Ochieng et al. 2002). These organs are probably related to the detection of sexual pheromone released by females.

In the laboratory, L. marginaticollis flight began by the time the insects left the soil, which might have occurred for many purposes as dispersal, foraging or even for breeding. Such behavior was also recorded for L. albopilosus (according to Ferreira et al. 2016) and Anomala testaceipennis Blanchard, 1851 (Rodrigues et al. 2014).

Facundo et al. (1999) reported that adults of Exomala orientalis Waterhouse, 1875 leave the ground but do not fly, and females rub the 
third pair of legs against the abdomen, what might be to the releasing of sex pheromone to attract males (Facundo et al. 1999). In our study, no similar behavior was observed for $L$. marginaticollis females concerning the releasing of sexual pheromone for males attraction.

After accepting the males, females remained for on average 22.71 minutes mating. For L. albopilosus, mating lasts for 19.45 minutes on average (Ferreira et al. 2016). Both L. marginaticollis and L. albopilosus have a similar mating time since, according to Ferreira et al. (2016), for the latter it occurs from 7:00 p.m. to 11:00 p.m. Martínez et al. (2013) also reported that adults of $L$. femoratus perform mating from 8:00 p.m. to 11:00 p.m..

Interestingly, several females of $L$. marginaticollis refused to mate with males, escaping from them during male mating attempts. Similar behaviors were observed for L. albopilosus (according to Ferreira et al. 2016), A. testaceipennis (according to Rodrigues et al. 2014), and Liogenys fusca Blanchard, 1850 (Rodrigues et al. 2016).

As stated by Ferreira et al. (2016), adults of L. albopilosus were collected in larger numbers from 8 p.m. to 10 p.m., which was also the period of greatest occurrence of $L$. marginaticollis in this study.

Adults of L. marginaticollis fed on leaves, flowers, and fruits of various plant species, showing that they have a wide range of food sources. Adults of L. albopilosus can feed on banana fruits (Musa sp., Musaceae) and mango flowers (Hancornia speciosa Gomes, Apocynaceae). According to Rodrigues et al. (2014), adults of A. testaceipennis feed on flowers of oiti (Licania tomentosa (Benth.) Fritsch., Chrysobalanaceae) and flowers of laurel (Cordia glabrata (Martius) A.DC., Boraginaceae).

In the present study, we obtained a great deal of information on the mating behavior of $L$. marginaticollis, as well as information regarding the flight time, feeding habits, widening the existing background on the genus Leucothyreus.

\section{Acknowledgments}

Kleyton R. Ferreira was granted a scholarship from CAPES. Sergio R. Rodrigues was granted financial supported from CNPq (305260/2014-6). This work was supported by Fundação de Apoio ao Desenvolvimento do Ensino, Ciência e Tecnologia do Estado de Mato Grosso do Sul (FUNDECT) (Process n. 217/2016).

\section{Author's Contribution}

Kleyton Rezende Ferreira: Contribution to data collection, contribution to data analysis and interpretation, contribution to manuscript preparation and contribution to critical revision, adding intellectual content.

Sérgio Roberto Rodrigues: Contribution to data analysis and interpretation, contribution to manuscript preparation and contribution to critical revision, adding intellectual content.

\section{Conflicts of interest}

The authors declare that they have no conflict of interest related to the publication of this manuscript.

\section{References}

FACUNDO, I.I.T., LINN, C.E., VILLANI, M.G. \& ROELOFS, W.L. 1999. Emergence, mating and postimating behaviors of the oriental beetle (Coleoptera: Scarabaeidae; Scarabaeinae). J. Insect Behav. 12(2):55-64.

FERREIRA, K.R., GOMES, E.S. \& RODRIGUES, S.R. 2016. Biological aspects and maing behavior of Leucothyreus albopilosus (Coleoptera: Scarabaeidae). Rev. Biolog. Trop. 64(2):547-557. http://dx.doi.org/10.15517/rbt.v64i2.19249

GOMES, E.S., RODRIGUES, S.R. \& MORÓN, M.A. 2014. Biological aspects of Leucothyreus ambrosius Blanchard (Coleoptera, Melolonthidae, Rutelinae). Rev. Bras. Entomol. 58(2):198-202.http://dx.doi.org/10.1590/S0085-56262014000200011
JAMESON, M.L. \& HAWKINS, S.J. 2005. Synopsis of the genera of Geniatini (Coleoptera: Scarabaeidae: Rutelinae) with an annotated catalog of species. Zootaxa 874(7):1-76.

KÖPPEN, W. 1948. Climatologia: com um estudio de lós climas de la tierra. México: Fondo de Cultura Econômica, 312p.

MARTÍNEZ, L.C. \& PLATA-RUEDA, A. 2013. Some biological aspects of Leucothyreus femoratus (Burmeister) (Coleoptera, Scarabaeidae), in oil palm plantations from Colombia. J. Entomol. Acarol. Res. 45(7):27-32.

MARTÍNEZ, L.C., PLATA-RUEDA, A., ZANUNCIO, J.C. \& SERRÃO, J.E. 2013. Leucothyreus femoratus (Coleoptera: Scarabaeidae): Feeding and behavioral activities as an oil palm defoliator. Fl. Entomol. 96(1):55-63.

MORÓN, M.A. 2004. Melolontídeos edafícolas. In Pragas de Solo No Brasil (J.R. Salvadori, C.J. ÁVILA \& M.T.B. SILVA, eds.). Embrapa-CNPT, Passo Fundo, EMBRAPA-CPAO, Dourados, Fundacep Fecotrigo, Cruz Alta, p.133-166.

OCHIENG, S.A., ROBBINS, P.S., ROELOFS, W.L. \& BAKER, T.C. 2002. Sex pheromone reception in the scarab beetle Phyllophaga anxia (Coleoptera: Scarabaeidae). Ann. Entomol. Soc. Am. 95:97-102.

PARDO-LOCARNO, L.C., MONTOYA-LERMA, J. \& SCHOONHOVEN, A.V. 2003. Abundancia de chisas rizófagas (Coleoptera: Melolonthidae) en agroecossistemas de Caldono y Buenos Aires, Cauca, Colombia. Rev. Colomb. Entomol. 29(2):177-183.

PARDO-LOCARNO, L.C., MONTOYA-LERMA, J., BELLOTTI, A.C. \& SCHOONHOVEN, A.V. 2005. Structure and composition of the white grub complex (Coleoptera: Scarabaeidae) in agroecological systems of Northern Cauca, Colombia. Fl. Entomol. 88(4):355-363.

PARDO-LOCARNO, L.C., MORÓN, M.A. \& MONTOYA-LERMA, J. 2006. Descripción de los estados inmaduros de Leucothyreus femoratus Burmeister (Coleoptera: Melolonthidae: Rutelinae: Geniatini) con notas sobre su biología e importancia agrícola en Colombia. Fol. Entomol. Mex. 45(2):179-193.

PEREIRA, A.F., RODRIGUES, S.R. \& MORÓN, M.A. 2013. Biological aspects of Leucothyreus alvarengai Frey and Leucothyreus aff. semipruinosus Ohaus (Coleoptera, Melolonthidae, Rutelinae) in crop succession at central Brazil. Rev. Bras. Entomol. 57(3):323-328. http://dx.doi.org/10.1590/S0085-56262013005000028

PUKER, A., RODRIGUES, S.R., TIAGO, E.F. \& SANTOS, W. T. 2009. Espécies de Scarabaeidae fitófagos (Insecta: Coleoptera) associadas ao sistema radicular de Acrocomia aculeata (Jacq.) Lodd. Ex Mart. (Arecaceae). Biota Neotrop. 9(3):105-109.

PUKER, A., MORÓN, M.A., OLIVEIRA JUNIOR, O. \& MESSAGE, D. 2011. First record of Leucothyreus albopilosus (Coleoptera: Scarabaeidae: Rutelinae: Geniatini) in lesions on stem of Eucalyptus citriodora and beehives of Apis mellifera. Entomol. Sc. 14(2):230-233.

RAMÍREZ-SALINAS, C. \& CASTRO-RAMÍREZ, A.E. 2000. El complejo "gallina ciega" (Coleoptera: Melolonthidae) en el cultivo de maíz, en El Madronal, municipio de Amatenango Del Valle, Chiapas, México. Act. Zool. Mex. (n.s.) 79:17-41.

RODRIGUES, S.R. \& PEREIRA, A.F. 2014. Scarabaeidae pragas em sucessão de soja e algodão em Campo Novo dos Parecis, MT. Rev. Agric. Neotrop. 1(1):38-43.

RODRIGUES, S.R., PUKER, A. \& TIAGO, E.F. 2010. Aspectos biológicos de Leucothyreus dorsalis Blanchard (Coleoptera, Scarabaeidae, Rutelinae). Rev. Bras. Entomol. 54(3):431-435.

RODRIGUES, S.R., GOMES, E.S. \& BENTO, J.M.S. 2014. Sexual dimorphism and mating behavior in Anomala testaceipennis. J. Insect Sci. 14:1-5.

RODRIGUES, S.R., MORÓN, M.A., GOMES, E.S. \& BENTO, J.M.S. 2016. Morphology of immature stages and mating behavior in Liogenys fusca (Blanchard) (Coleoptera, Melolontidae, Melolonthinae). Rev. Bras. Entomol. 60(4): 458-464.

ROMERO-LÓPEZ, A.A., ARZUFFI, R., VALDEZ, J., MORÓN, M.A., CASTREJÓNGÓMEZ, V. \& VILLALOBOS, F.J. 2004. Sensory organs in the antennae of Phyllophaga obsoleta (Coleoptera: Melolonthidae). Ann. Entomol. Soc. Am. 97:1306-1313

SILVA, F.A.Z. \& AZEVEDO, C.A.V. 2002. Versão do programa computacional Assitat para o sistema operacional Windowns. Rev. Bras. Prod. Agroindustr. 4(1):71-78.

Received: 02/02/2017

Revised: 07/11/2017

Accepted: 13/11/2017

Published online: 11/12/2017 